\title{
LEARNING OBJECTS AND THEIR RESOURCES ON THE INTERNET
}

\section{Vladimíra SEHNALOVÁ}

\begin{abstract}
When preparing for the lesson with use of ICT, teachers are not dependent only on selfproduced electronic teaching texts, objects and tools any more. In addition to learning software, there is another source of information - the Internet, where one can find a wide range of digital teaching materials. This paper will show examples of some of these resources.
\end{abstract}

Key words: digital teaching materials, electronic teaching tools, open learning objects, on-line learning resources.

\section{VÝUKOVÉ OBJEKTY A JEJICH ZDROJE NA INTERNETU}

Resumé: Při př́pravě na vyučování pomocí ICT není již učitel odkázán jen na vlastní vyrobené elektronické učební texty, objekty a pomůcky. Kromě výukových programů je dalším zdrojem informaci Internet, kde je možno najít celou řadu digitálních výukových materiálü. Přispěvek uvádí príklady některých těchto zdrojü.

Klíčová slova: digitální výukové materiály, elektronické učební pomůcky, otevřené výukové objekty, on-line výukové zdroje.

\section{1 Úvod}

$\mathrm{Na}$ školách se stal počítač důležitým pomocníkem při vzdělávání v různých vyučovacích předmětech. Jednou $\mathrm{z}$ forem využití je výukový software zaměřený na daný předmět. Výrobce programu nejčastěji multimediální formou zpracovává danou problematiku. Spojení textu, zvuku a obrazu tak může současně působit na smyslové vnímání žáků. Dochází k vizualizaci pojmů, které vede $\mathrm{k}$ lepšímu pochopení a zapamatování probíraného učiva. Digitální výukové materiály jsou tak důležitou součástí využívání ICT při výuce jednotlivých vyučovacích předmětů na základních a středních školách.

Elektronické učební pomůcky si učitel často připravuje a vyrábí sám podle svých představ. Tvorba těchto materiálů se stala důležitou součástí informačních a komunikačních kompetencí učitele. Předpokládá kromě odborných znalostí dostatek znalostí technických a vhodnou technickou podporu. Učitel si připravuje elektronické výukové materiály, jako jsou prŕípravy na hodinu, zadání pro žáky nebo prezentace k probírané látce. Může vytvářet celé výukové opory, elektronické učebnice nebo další vzdělávací objekty. Př́íprava takových učebních materiálů a textů je technicky i časově náročná. Jednou z možností je využít některých hotových produktů profesionálních firem. Existují již studijní materiály v multimediální podobě, audio a video studijní materiály nebo multimediální a interaktivní učebnice.

Důležitou součástí vzdělání se stávají také online informace. Nejedná se jen o elektronické informační zdroje, které obsahují učební a výukové objekty, mohou to být různé typy informačních zdrojů Internetu, které učitel může ve výuce využít. Jsou jimi např́íklad elektronické odborné časopisy, vzdálená laboratoř pro pozorování pokusů on-line, úložiště výukových objektů nebo otevřené výukové zdroje. Součástí digitálních výukových materiálů mohou také být interaktivní a ilustrativní animace, applety jako interaktivní prvky nebo animace Macromedia Flash.

\section{Elektronické výukové objekty}

Výukový objekt je libovolný objekt, který může být použit k učení, vzdělávání a výuce. Jeho forma může být digitální nebo nedigitální. Mezi elektronické (digitální) výukové objekty patří text, obrázky, zvuky a videa, které mohou být dále sestaveny do celých elektronických kurzů. Pro opakované použití a jejich vyhledání musí autor výukový objekt detailněji popsat, opatřit je dalšími informacemi o objektu samém (obsah, autor, typ školy, věková skupina žáků atd.), tzv. metadata.

Vznikají úložišstě výukových objektů, jejichž zřizovatelem může organizace státního sektoru, nezisková organizace, vysoká škola, př́ípadně další, kteří chtějí učitelům pomoci se získáváním digitálního obsahu. Výukové objekty jsou na 
serveru uloženy do úložiště $\mathrm{s}$ hierarchickou podobou uspořádání dokumentů. Pro vyhledávání úložišt' jsou vytvářeny metadatové vyhledávače objektů, které výukové objekty neshromažd’ují, ale jednotlivé objekty jsou zde indexovány formou metadat. [1]

\section{Otevřené výukové objekty}

Interaktivní výukové objekty byly vytvářeny společně se zaváděním interaktivních tabulí do škol. Velmi rychle vznikla také komunita uživatelů, ochotných své výukové programy předávat jiným učitelům a současně čerpat nápady svých kolegů. Takové výukové zdroje jsou pak otevřenými zdroji, které si uživatel může stáhnout a následně podle svých představ upravit.

Open education resources (OER) jsou rozšířené i na portálech Evropské unie věnované výuce. Otevřené vzdělávací zdroje nabízí kurzy, výukové materiály, sbírky, časopisy, software pro podporu tvorby materiálů a možnost tyto zdroje dále upravovat. Jsou jimi např́klad MELT, CALIBRATE, ze světových MERLOT nebo OER Commons. Nevýhodou takto umístěných zdrojů po celém světě je pracnost při jejich vyhledávání, možné technické problémy, kvalita výukových objektů a vhodnost využití ve výuce. [2]

\section{MITOPENCOURSEWARE - Massachusetts Institute of Technology}

Stránky MIT OpenCourseWare (OCW) obsahují volně př́stupné materiály univerzitních kurzů, které pokrývají téměř všechny pregraduální a postgraduální předměty vyučované na univerzitě MIT. Kurzy jsou určeny také studenti̊m ze zahraničí, kteří pro své studium nemají dostatek odborných materiálů. Stránky jsou překládány do dalších jazyků, pod odkazem Překlad kurzů je možno nalézt výběr z jazyků např. thajsky, persky, portugalsky, španělsky atd. MIT OpenCourseWare je využíván různými skupinami $\mathrm{z}$ celé řadu důvodů. Učitelé mohou zlepšit své osobní znalosti, naučit se nové vyučovací metody nebo začlenit materiály do svých kurzů. Studenti mohou sledovat aktuální vývoj svého oboru, objevit nové poznatky pro svou budoucí profesi a najít materiály pro vypracování svého úkolu nebo projektu. [3]

\section{Connexions}

Vytváŕí prostředí pro spolupráci, rozvoj a sdílení vzdělávacích materiálů pro každého - od studentů pro profesionály - uspořádaných do modulů, které je možno připojit do větších sbírek nebo kurzů. Proč znovu objevovat objevené? Když lidé sdílejí své znalosti, mohou si vybrat $\mathrm{z}$ nejlepších nápadů a $\mathrm{z}$ nich pak vytvořit účinné učební materiály. Connexions je místo k prohlížení a sdílení vzdělávacích materiálů sestavených z informačních modulů, které mohou být uspořádány jako kurzy, knihy, zprávy atd. Každý si je může prohlédnout nebo přispět. [4]

\section{$N A S A$}

NASA pomáhá učitelům nalézt vzdělávací zdroje, které mohou být použity ve výuce. Uživatelé mohou vyhledávat podle klíčových slov, typu media, předmětu nebo modulu. Portál nabízí celou řadu textů, obrázků, videí a vzdělávacích projektů, využitelných na všech typech škol. Dále nabízí studentům i učitelům neformální prostředky jejich vzdělávání, besedy, soustředění, školení, poradenství a studijní materiály. [5]

\section{ORIGIN - soutěže o nejlepší elektronický výukový materiál}

Organizátoři soutěže oslovili v roce 2008 aktivní učitele, kteří vytvářejí elektronické výukové materiály a nabídli jim možnost představení svých výtvorů s možností porovnat je a vyhodnotit. $Z$ přihlášených prací porota vybrala ty nejlepší a finalisté se utkali 12. prosince 2008 v Ostravě. Autor výukového materiálu měl na předvedení 15ti minutový limit a kromě vlastní prezentace měl zdůvodnit jeho metodické využití a odpovědět na př́ípadné dotazy poroty. Pozitivně byla účastníky hodnocena při této prríležitosti výměna zkušeností, možnost inspirace, ukázky využití ICT ve vzdělávání a vzájemné srovnání prací soutěžících pedagogů. Vítězné práce jsou umístěny na stránkách České školy v článku o této soutěži, je možné si je stáhnout, prohlédnout a nechat se inspirovat. [6]

\section{Další výukové zdroje na Internetu}

Následující text přináší přehled různých portálů a stránek, které by učitelé mohli využít ve výuce. Je uveden stručný popis a URL odkaz na www stránky. Bylo by škoda nevyužít dobrých nápadů a hodin práce věnovaných tvorbě takovýchto on-line studijních materiálů.

\section{Ve škole}

Mezi české portály patří např́ílad Ve škole portál na podporu interaktivní výuky. Portál poskytuje podporu aktivním uživatelům 
interaktivních tabulí a moderních technologií ve výuce. Učitelé zde mohou najít články, informace o semináŕích, ale hlavně celou řadů materiálů, které poskytli jejich tvůrci - učitelé.

Zdroj: http://www.veskole.cz/

Digitální učební materiály - Prostor pro učitele, kteři hledají, tvoři a sdilí učební materiály

Portál nabízí pracovní listy, prezentace, texty, videa a zvukové ukázky pro využití ve výuce, které jsou distribuovány elektronicky. Neregistrovaný uživatel si může prohlížet a stahovat materiály jiných kolegů. Registrace pak přináší další možnosti jako vytváření vlastních kolekcí materiálů, možnost komentovat a hodnotit materiály ostatních uživatelů, získávat informace o ostatních uživatelích, psát vlastní blog nebo dokonce obdržet honoráře za zveřejněné materiály.

Zdroj: http://dum.rvp.cz/index.html

\section{WebQuest}

Portál seznamuje zájemce s inovativním způsobem konstruktivního uplatnění vzdělávacích technologií ve výukovém procesu. Představuje WebQuesty, jejich strukturu a typy, taxonomii WebQuestových úloh a doporučení pro jejich tvorbu. Archiv WebQuestů pak nabízí již vytvořené projekty. Vyhledávat je lze podle typu školy, ročníku nebo předmětu. Přehledná tabulka nabízí informace o počtu zadání tohoto WebQuestu a ohodnocení pomocí hvězdiček. Zájemce si bez registrace může projekty prohlédnout. Po registraci má možnost založit nový projekt podle již vytvořeného, př́ípadně jednotlivé fáze WebQuestu upravit pro použití ve vlastní výuce.

Zdroj: http://www.webquest.cz/

\section{Výukový portál Olomouckého kraje}

Portál tvoří internetové rozhraní mezi uživateli, kterými jsou žáci, studenti a učitelé různých typů škol a tvưrci, kteří se na vývoji pomůcek podílejí. Základem týmu pro návrh a vývoj aplikací a pomůcek jsou učitelé a studenti katedry informatiky PřF UP v Olomouci. Po registraci se uživatelé mohou účastnit diskusních fór k jednotlivým oblastem či pomůckám, mohou sdělit svůj názor a doporučit zlepšení. Pomůcky se tak mohou za jejich přspění dále vyvíjet a vylepšovat.

Zdroj:

http://webvyuka.olportal.cz/Screens/Default.aspx

\section{Popularis}

Původní cyklus České televizi vznikal v letech 2003 až 2006, představil českou vědu a výzkum v kontextu vědy evropské a světové. Dnes lze najít na www stránkách videoarchiv, přehled pořadů zařazených do vědních oborů, popis pořadu a rozšířený text pořadu $\mathrm{v}$ dokumentu Wordu. Lze přehrát záznam každého pořadu.

Zdroj:

http://www.ceskatelevize.cz/program/109596946 1.html

\section{ICT v učivu elektromotorů na SS̆}

Elektronické internetové učebnice fyzikálních základů činnosti elektromotorů. Po výběru jedné ze čtyř uvedených škol se zobrazí obsah kapitol, který vychází ze společných požadavků učebních osnov jednotlivých studijních nebo učebních oborů. Obsah učiva může být vyučujícím rozšířen.

Zdroj: http://www.emotor.cz/

\section{Merlingo - Academic rich media repository}

Hlavním cílem projektu Merlingo je vybudování centrálního úložiště vzdělávacích objektů s prezentacemi pedagogů v prostředí národní počítačové sítě CESENT2 podporující synchronní služby virtuálních univerzit a umožňujících nasazení technologií Mediasite Recorder na veřejných vysokých školách v ČR. Na portále jsou uloženy prezentace dle vysokých škol, pod odkazem Ostatní prezentace lze pak najít záznamy z konferencí, MŠMT nebo dalších institucí.

Zdroj: http://www.merlingo.cz/

\section{Fyzikální Java applety, Matematické Java applety}

Autor Walter Fendt poskytuje své applety kolegům vyučujícím na ostatních školách. Je povoleno si vytvářet kopie HTML textů a appletů pouze pro nekomerční využití.

Zdroj: $\quad$ http://www.walter-fendt.de/ph14cz/, http://www.walter-fendt.de/m14cz/

\section{Cabri Geometrie}

Portál pro podporu výuky geometrie pomocí počítače vznikl iniciativou několika vysokoškolských pracovišt' v roce 1999. Př́spěvky a články různého technického provedení tvořilo několik autorů v průběhu několika let. Naleznete zde text, obrázky, interaktivní applety nebo články doplněné originálními Cabri obrázky ke stažení. Příspěvky jsou setříděny pro běžného uživatele (jak kreslit), 
pro učitele (jak učit pomocí počítače), matematické a technické články a zajímavosti.

Zdroj: http://www.pf.jcu.cz/cabri/

\section{Mindsensoers.com}

Návrh a vývoj pokročilých elektronických výrobků pro vzdělávání a zájmové aplikace.

Portál nabízí formou video ukázek sestavy vytvořené pomocí různých stavebnic. Autoři navrhují a vyvíjejí pokročilé elektronické výrobky pro vzdělávání a zábavu. Portál dále nabízí ukázky programů a návody pro jednotlivé typy ovládacích prvků.

Zdroj: http://www.mindsensors.com/

\section{Elektronický učitel - výukové programy pro učitele a žáky}

Autor RNDr. Jiří Kocourek si na počátku výukové programy vytvářel sám. Na základě př́znivého ohlasu jeho kolegů ho napadlo zpř́stupnit dosavadní práci také ostatním. Okamžitý a kladný ohlas na založení portálu překonal všechna autorova očekávání a další učitelé pak nabídli ke zveřejnění své práce. Zapojení do projektu je možné na několika úrovních - od šiření informací o tomto portálu, přes registraci uživatele a rozšířené služby, recenzi a úpravu existujících aplikací až po publikaci vlastních zcela nových programů.

Zdroj: http://www.eucitel.cz

\section{Elektromagnetické vlny, Mikrovlnná technika, multimediální učebnice}

Autoři učebnice chtějí na konkrétních př́kladech vysvětlit praktický význam komplikovaných matematických operátorů. Učebnice vizualizuje zkoumané jevy, aby si studenti mohli vytvořit správnou představu o jejich podstatě a zákonitostech. Učebnice chce ukázat, kde a jak lze využít zkoumaných jevů $\mathrm{v}$ inženýrské praxi.

Zdroj:

http://www.urel.feec.vutbr.cz/ raida/multimedia/ index.php

\section{Modul ICT ve výuce českého jazyka a literatury}

Modul je zaměřen na funkční využití ICT ve složkách předmětu český jazyk a literatura, tj. ve složce jazykové, literární, ve slohové a komunikativní výchově, ve vyučování na ZŠ a na SŠ. Portál dále nabízí elektronickou učebnici Multimediální prvky vjazykovém vyučování ve tř̌ech úrovních náročnosti (základní, středně pokročilý, pokročilý). Ke stažení jsou pak dostupné prezentace a metodické prríručky.
Zdroj:

http://athena.zcu.cz/ecestina/kurz/index.php

\section{Soutěže}

Soutěže mohou tvořit další skupinu výukových zdrojů. Pokud vyučující nalezne na stránkách vyhlášené soutěže také ukázky vítězných prací z předchozích let, mohou být tyto žákovské a studentské práce vhodnou motivací pro vlastní práci studentů $\mathrm{v}$ dané oblasti.

\section{Internetové soutěže}

Tvorbě www stránek se věnují studenti základních i středních škol. Pro rok 2009 byly vyhlášeny celkem čtyři témata pro různé věkové kategorie studentů. Soutěž JuniorWeb je určena mladým lidem, kteří vytváří vlastní webové stránky či různé internetové služby a projekty. JuniorDesign je soutěž designů a grafických návrhů, JuniorText pak soutěž textů na zadaná témata týkající se Internetu, kde se hodnotí slohová obratnost i myšlenkový obsah a JuniorErb jako soutěž webových stránek pro města, obce, regiony, turistická místa či veřejnou správu. V části Vitězné práce jsou pak umístěny odkazy na ukázky nejlepších prací přechodních ročníků.

Zdroj:

http://www.juniorinternet.cz/competitions.php

\section{Programátorské soutěže s Baltikem - pro žáky i studenty}

Programátoři $\mathrm{v}$ Baltíkovi se mohou účastnit celé řady soutěží, v nichž si mohou změřit své schopnosti $\mathrm{s}$ ostatními mladými programátory $\mathrm{u}$ nás i v zahraničí, mají možnost se pochlubit svými programy nebo naopak získat zkušenosti od ostatních. Ing. Jiří Sumbal, učitel informatiky na ZŠ a SŠ: „Právě díky soutěžím v Baltíkovi získali moji žáci tu správnou motivaci a učinili ty největší pokroky. “

Zdroj: http://souteze.sgpsys.com/

\section{Zoner Callisto grafik}

Soutěž Zoner Callisto grafik je soutěž v kreslení na počítači pomocí grafického editoru Zoner Callisto. Pořadatelem a zároveň odborným garantem soutěže je společnost ZONER software. Soutěž probíhá ve dvou kategoriích: Mladý Callisto grafik, kategorie pro účastníky ve věku od 6 do 14 let a Design Callisto grafik, kategorie pro účastníky ve věku od 15 do 18 let. Pod záložkou Výsledky si žáci mohou prohlédnout vítězné práce předchozích ročníků a inspirovat se pro vlastní práci. 
Zdroj: $\quad$ http://www.zoner.cz/akce/soutez-zonercallisto-grafik-pravidla.asp

\section{Závěr}

On-line může učitel najít velké množství vhodných výukových digitálních objektů. Je jen na něm, zda si elektronické výukové zdroje vyhledá, seznámí se s jejich obsahem a vhodně zařadí do výuky. Prohlížení již hotových prvků pak pro něj může být inspirací pro vytváření vlastních učebních objektů.

\section{Literatura}

[1] NEUMAJER, O. Elektronické výukové objekty a jejich úložiště $v \check{C} R$ [online]. [01.01.08 v 23:59:00], [cit. 09-03-28]. Dostupné na www: $<\mathrm{http}$ ://ondrej.neumajer.cz/?item=elektronic ke-vyukove-objekty-a-jejich-uloziste-v-cr> .

[2] HAUSNER, M. Otevřené výukové objekty nový trend ve výukovém softwaru [online]. [11.09.2008 09:08], [cit. 2009-03-28], Dostupné na ww: $<$ http://veskole.cz/(Ojg2)/a2184_otevrenevyukove-objekty---soucasny-trend.html>.

[3] MITOPENCOURSEWARE - Massachusetts institute of technology [online]. 2002-2009
MIT. [cit. 2009-03-22]. Dostupné na www: http://ocw.mit.edu/OcwWeb/web/home/hom e/index.htm.

[4] CONNEXIONS [online]. [cit. 2009-03-22]. Dostupné na www: <http://cnx.org/>.

[5] NASA [online]. Page Last Updated: January 19, 2009, [cit. 2009-03-30]. Dostupné na www:

$<$ http://www.nasa.gov/home/index.html $>$.

[6] KOCICHOVÁ, D. Výsledky soutěže o nejlepši výukový materiál ORIGIN [online]. [6.1.2009], [cit. 09-03-28]. ISSN 1213-6018. Dostupné na www: $<$ http://www.ceskaskola.cz/ICTveskole/Ar.a sp?ARI $=105657 \& \mathrm{CAI}=2129>$.

Mgr. Vladimíra Sehnalová

Katedra informatiky a počítačů

Přírodovědecká fakulta

Ostravská univerzita v Ostravě

30. dubna 22

70103 Ostrava

tel.: +420 597092182, +420 738512182

vladimira.sehnalova@osu.cz

http://www.osu.cz/fpr 